\title{
THE "GREEN JOBS" FANTASY: WHY THE ECONOMIC AND ENVIRONMENTAL REALITY CAN NEVER LIVE UP TO THE POLITICAL PROMISE
}

\author{
Jennifer Winter and Michal C. Moore ${ }^{\dagger}$ \\ The School of Public Policy, University of Calgary
}

\section{SUMMARY}

Agriculture is one of the least "green" - that is, the least environmentally friendly - sectors in Canada, based on its energy-use intensity and greenhouse gas emissions intensity. But agriculture is also the "greenest" sector in Canada, according to one measure that calculates the proportion of "green employment" in various industries. Welcome to the world of "green jobs," where vague definitions often give energy-intensive, carbon-heavy industries a "green" stamp of approval. Examples include companies making solar panels, but using large volumes of energy to do so or where an accountant preparing financial returns is counted as a "green" worker at one office, but turns instantly "dirty" should he cross the street to do the same accounting work at another office. It is also a world where inefficient power generation is considered positive, if it means employing more "green workers" per unit of power output, regardless of any negative effects that may have on the economy.

The concept of "green jobs" has become immensely popular among policy planners looking to address the problem of global warming, yet are aware of the economic costs of anti-carbon measures. The promise that western economies can reduce carbon emissions while creating thousands, if not millions, of "green jobs" which will more than compensate for the job losses that will occur in sectors reliant on fossil fuels - has been especially embraced by politicians, relieved to find a pro-climate policy that also doubles as a pro-economic policy. Unfortunately, there is scant agreement on what fairly qualifies as a "green job," and much evidence that what policy-makers frequently consider "green jobs" are, in fact, existing jobs, belonging to the traditional economy, but simply reclassified as "green."

By emphasizing "green jobs," policy-makers risk measuring environmental progress based on a concept that can often be entirely irrelevant, or worse, can actually be detrimental to both the environment and the economy. Too often, "green job" policies reward inefficiency, while also failing to distinguish between permanent, full-time jobs and temporary or part-time jobs. In some cases they can also discourage trade, limit or thwart competition, result in greater job losses elsewhere in the economy, and demand massive government subsidies, with some government "green job" programs requiring hundreds of thousands of dollars, or even millions, to create a single job.

The urge of politicians to champion "green employment" is understandable given its convenient, if frequently unrealistic promise of a politically saleable anti-carbon policy. However, a more reliable and meaningful measure of environmental progress ultimately has little to do with the number of jobs a particular company creates (after all, if economic efficiency - and hence, prosperity - is indeed a policy goal, the number of jobs created should ideally be as minimal as necessary for every unit of output). Rather, if minimizing energy use and greenhouse gas emissions is the desired policy outcome, then measuring the intensity of energy use and greenhouse gas emissions per unit of output can be the only meaningful metric. It may not have the political appeal that a promise of "green jobs" does. But unlike "green jobs," both of these measures provide quantifiable, non-arbitrary metrics of environmental performance and progress. In other words, unlike the problematic, arguably illusory concept of "green employment," measuring energy-use intensity and emissions intensity actually tells us very clearly and reliably whether we are making the environment better or worse. 


\section{INTRODUCTION}

There is a growing trend among employers, governments and NGOs to identify and give credit to a category of jobs that can be segregated and discretely defined as "green." This comes out of growing concern over climate change and global warming, but also concern over the economic consequences of actions to mitigate carbon emissions. Several Conservative members of Parliament have gone on record in the House of Commons stating that a carbon tax would "raise the price of everything" and Conservative MP Bernard Trottier referred to a carbon tax as "jobkilling."

The promise of green jobs appears to be a way of addressing two policy issues at once: employment and environmental improvements. Policy-makers can argue that green-job creation will compensate for jobs lost due to more stringent environmental policy. In a 2008 speech, then-president-elect Barack Obama stated, "My presidency will mark a new chapter in America's leadership on climate change that will strengthen our security and create millions of new jobs in the process." ${ }^{2} \mathrm{He}$ went on to proclaim that investing in clean energy technologies will "help us transform our industries and steer our country out of this economic crisis by generating five million new green jobs that pay well and can't be outsourced." The "Green Shift" plan championed by Canada's federal Liberal party during the 2008 election argued that a carbon tax would create green jobs.

Much of the attraction of this term stems from consumer interest and preference for labelling that highlights the value of natural systems or a more proactive stance toward the environment. As well, there is currently a strong focus in the media on threats to the natural environment combined with government and policy interest in "solutions" that may serve to mitigate adverse environmental trends. "Green jobs" neatly fits in all of these categories.

This paper discusses the emerging trend in creating and integrating so-called "green employment" or green jobs into the traditional economy. The characterization of "green-ness" is a new and, at present, relatively imprecise term. The term has been used to complement the goal of achieving a greener, and more sustainable economy than that offered by traditional employment categories, and one focused on aggregate production and consumption with minimal net impacts on the biosphere as well as social systems. Nevertheless, many consider the green sector to be a real and important part of economies today. For many, there is value in measuring the size of, as well as accurately defining, the green sector.

There are easily as many definitions of green jobs as there are reports discussing the sector. Common themes in the discussion of green jobs and the green or clean economy include the use of renewable energy, improved energy efficiency, pollution prevention and mitigation, and resource conservation. One of the difficulties in measuring and defining green jobs is that the

1 Canada. House of Commons Debates, May 6-10, 2013 (Mr. Bernard Trottier, CPC) http://www.parl.gc.ca/housechamberbusiness/chambersittings.aspx.

2 Office of the President-Elect, News Release, "President-elect Obama promises 'new chapter' on climate change," November 18, 2008, http://change.gov/newsroom/entry/president_elect_obama_promises_new_chapter_on_climate_change/. 
"sector" is (potentially) included in all parts of an economy. The jobs themselves are spread across traditional industry definitions. Traditional industries are classified by their output, rather than the types of inputs. The distinction of "green" does not necessarily represent new growth in the economy, but rather redefined growth. ${ }^{3}$

To quote the Worldwatch Institute, " "[i]n an ideal state of affairs, a green economy is one that does not generate pollution or waste and is hyper-efficient in its use of energy, water, and materials. Using this green utopia as a yardstick would mean that currently there are few, if any, green jobs. A more realistic, pragmatic approach is process-oriented rather than fixated on an ideal yet elusive end-state. In other words, green jobs are those that contribute appreciably to maintaining or restoring environmental quality and avoiding future damage to the Earth's ecosystems" (emphasis added).

Policy-makers have an appropriate concern about the definition of green jobs and the contribution of the green economy for a variety of reasons. First and foremost, green jobs are often claimed to be a benefit or outcome of environmental policies. ${ }^{5}$ Second, given the potential problems of climate change, economies require "greening." Third, there is increased consumer demand for "green" products. Given the uncertainty referenced above, policies to create green jobs may best be separated from policies designed to improve environmental quality. It is possible that green-job creation will be a beneficial side-effect of policies to improve environmental standards, but these policies should be judged on their merits, based on this objective, rather than job creation (green or otherwise).

Much of the impact associated with job growth depends on the metric used for comparison. For instance, Kammen et al. state that in terms of energy delivered, investment in the renewable-energy sector created more employment than the fossil-fuel-based energy sector per unit of energy delivered when measured on the basis of jobs per average megawatt. ${ }^{6}$ Wei et al. synthesize data from 15 previous studies on the job-creation potential of non-fossil-fuel energy sources for the U.S., finding non-fossil-fuel technologies create more jobs per unit of energy than coal or natural gas. ${ }^{7}$ This means, of course, that non-fossil-fuel technologies are more inefficient (on a per-job basis) at producing energy.

3 Bezdek et al. (Roger H. Bezdek, Roger M. Wendling and Paula DiPerna, "Environmental Protection, the Economy and Jobs: National and Regional Analyses," Journal of Environmental Management 86, 1 (2008) 63-79) find the vast majority of jobs in the environmental-protection industry are standard, and that even within environmental companies, the majority of employees are not classified as environmental specialists.

4 UNEP/ILO/IOE/ITUC, “Green Jobs: Towards Decent Work in a Sustainable, Low-Carbon World,” 2008.

5 For example, a report produced by ClearSky Advisors regarding Ontario's wind energy program states "the wind energy sector creates more employment opportunities per unit of energy produced and does so at a lower cost per job" (ClearSky Advisors, "The Economic Impacts of the Wind Energy Sector in Ontario 2011-2018," 2011). Robert Pollin et al. suggest that investing US $\$ 100$ billion in "six energy efficiency and renewable energy strategies" will create two-million jobs. ("Green Recovery: A Program to Create Good Jobs and Start Building a Low-Carbon Economy," Political Economy Research Institute, University of Massachusetts Amherst and Center for American Progress Report, 2008, http://www.americanprogress.org/issues/2008/09/pdf/green_recovery.pdf)

6 D. M. Kammen, K. Kapadia and M. Fripp, "Putting Renewables to Work: How Many Jobs Can the Clean Energy Industry Generate?” Renewable and Appropriate Energy Laboratory Report, University of California, Berkeley, 2004.

7 Max Wei, Shana Patadia and D. M. Kammen, "Putting renewables and energy efficiency to work: How many jobs can the clean energy industry generate in the US?" Energy Policy 38, 2 (2010) 919-931. 
Instead of focusing on green jobs as a policy goal, governments and policy-makers should concentrate on the issue of employment (or job creation) separately from the issue of environmental improvement. Focusing on green jobs confounds the issue of employment growth with environmental protection/mitigation. Often, green jobs are considered to be a metric of environmental progress. A better metric is improvements in energy use and energy use per unit of output, and greenhouse gas emissions and GHGs per unit of output. Both of these measures provide a quantifiable, non-arbitrary metric of environmental performance and progress.

In this paper, we first provide an overview of definitions advanced in the literature, followed by a review of critiques of the literature, and then provide a summary of previous work measuring green jobs in Canada. We follow with a discussion of the meaning of "green" in this context, and advance an alternative definition. We then provide a comparison of the relative greenness of Canadian industries. We conclude with recommendations regarding the future of green jobs as a policy goal.

\section{DEFINITION AND MEASUREMENT}

A green job ${ }^{8}$ presents a definitional challenge. There are many suggested alternatives available, but no broad literature or policy consensus has emerged. Before discussing our preferred definition, we provide a brief overview of potential definitions put forward by the various NGOs, think tanks, government organizations and academics studying green jobs. Some studies are mainly concerned with collating the number of green jobs, while others focus on job creation due to green policy initiatives.

\section{Green Jobs in the Literature}

The definition of a green job can be occupation-specific, industry-specific, reflect the underlying process or the output produced, or be very broad and inclusive. Different definitions are tabulated in Table 1; industry definitions, rather than job definitions are tabulated in Table 2. In the range of definitions presented in Tables 1 and 2, we find several common threads. These include conserving resources, use of renewable energy, and preserving or restoring environmental quality. However, despite the common threads, there are still many definitions of what "green" is.

Renner et al. note "efforts to boost the efficiency of energy, water, and materials use also involve some degree of 'green' employment. ' But because there is no clear threshold to define this efficiency, it can be difficult to decide which jobs are truly green." The definition suggested by Renner et al. is a "shades of green" argument - that the degree of conservation of resources defines the "greenness" of the job.

8 A colloquial variation is "green-collar" job.

9 Michael Renner, Sean Sweeney and Jill Kubit, “Green Jobs: Working for People and the Environment," Worldwatch Institute Report 177, 2008 
In contrast, a report produced by The Pew Charitable Trusts states there is a lack of consensus on what the term "green economy" means, and that "green" has "lost meaning, focus and value" through overuse. ${ }^{10}$ It instead chooses to define a "clean energy economy," a definition that focuses on the following areas: 1) clean energy; 2) energy efficiency; 3) environmentally friendly production; 4) conservation and pollution mitigation; and 5) training and support.

A report from the Brookings Institution defines the "clean economy" as economic activity "that provides goods and services with an environmental benefit or adds value to such products using skills or technologies that are uniquely applied to those products." 11 The authors note their definition is consistent with the United States Bureau of Labor Statistics (BLS) standard, and a slight variation on the definition used by the European Commission's statistical agency, Eurostat. The Brookings Institution definition only includes employment in industries that add value uniquely to green production - i.e., have "skills or technology unique to the clean economy" - while other studies use definitions that are broader.

One of the key differences among the various definitions offered is what is considered to be renewable or clean energy. Both the OECD ${ }^{12}$ and Eurostat ${ }^{13}$ exclude nuclear power from the definition of the environmental services, but include handling of nuclear waste. While nuclear power is not typically considered to be a renewable power source, Global Insight, ${ }^{14}$ Wei et al. ${ }^{15}$ Muro et al ${ }^{16}$ and the U.S. Bureau of Labor Statistics consider nuclear to be clean energy. In their discussion of renewable-energy production, Renner et al ${ }^{17}$ include hydro power, but exclude nuclear. ${ }^{18}$ As well, Worldwatch, ${ }^{19}$ The Pew Charitable Trusts, ${ }^{20}$ Greenpeace ${ }^{21}$ and IRENA $^{22}$ consider small-scale hydro or "low-impact" projects to be renewable, but not large

10 The Pew Charitable Trusts, "The Clean Energy Economy," 2009, http://www.pewenvironment.org/uploadedFiles/PEG/Publications/Report/Clean\%20Energy\%20Economy.pdf.

11 Mark Muro, Jonathan Rothwell and Devashree Saha, "Sizing the Clean Economy: A National and Regional Green Jobs Assessment," The Brookings Institution, Report, July 13, 2011, http://www.brookings.edu/research/reports/2011/07/13-clean-economy.

12 OECD, "The Environmental Goods \& Services Industry: Manual for Data Collection and Analysis," 1999.

13 Eurostat, "The environmental goods and services sector - a data collection handbook," 2009.

14 Global Insight, "U.S. Metro Economics: Current and Potential Green Jobs in the U.S. Economy,” October 2008, Report for The United States Conference of Mayors and the Mayors Climate Protection Center, http://www.usmayors.org/pressreleases/uploads/greenjobsreport.pdf.

15 Wei, Patadia and Kammen, "Putting renewables and energy efficiency to work."

16 Muro, Rothwell and Saha, "Sizing the Clean Economy."

17 Renner, Sweeney and Kubit, "Green Jobs: Working for People and the Environment."

18 Nuclear power is considered to be "dirty" by many groups because of potential hazards from the operation of plants as well as issues with nuclear-waste disposal.

19 UNEP/ILO/IOE/ITUC, “Green Jobs: Towards Decent Work in a Sustainable, Low-Carbon World,” 2008.

20 The Pew Charitable Trusts, "The Clean Energy Economy."

21 Jay Rutovitz and Alison Atherton, “Energy sector jobs to 2030: a global analysis," Prepared for Greenpeace International by the Institute for Sustainable Futures, University of Technology, Sydney, 2009, http://www.greenpeace.org/brasil/PageFiles/3751/energy-sector-jobs-to-2030.pdf.

22 International Renewable Energy Agency, "Renewable Energy Jobs: Status, Prospects \& Policies,” IRENA Working Paper, 2011, http://www.irena.org/DocumentDownloads/Publications/RenewableEnergyJobs.pdf. 
projects; Moore et al. ${ }^{23}$ exclude hydro greater than $30 \mathrm{MW}$ and Kammen et al..$^{24}$ exclude hydro altogether. Many renewable portfolio standards programs, for instance, disallow credit for large hydro projects on the grounds that the environmental impacts outweigh the "green" benefits and thus neutralize the categorical value or even the inclusion of this category.

ECO Canada has chosen to create separate definitions for green economy, green organizations and green jobs..$^{25}$ It defines the "green economy" as the "aggregate of all activity operating with the primary intention of reducing conventional levels of resource consumption, harmful emissions, and minimizing all forms of environmental impact. The green economy includes the inputs, activities, outputs and outcomes as they relate to the production of green products and services." A "green organization" is "one that produces goods or services designed to minimize environmental impact," while a "green job" is "one that works directly with information, technologies, or materials that minimize environmental impact, and also requires specialized skills, knowledge, training, or experience related to these areas." A second study published by ECO Canada provides a narrower definition based on the idea of environmental employment: "individuals who spend $50 \%$ or more of their work time on activities associated with environmental protection, resource management, or environmental sustainability." ${ }^{26}$

ECO Canada ${ }^{27}$ notes that limiting the definition of green jobs or the green economy to businesses that produce green products or services - the definition chosen by the OECD, ${ }^{28}$ Statistics Canada, ${ }^{29}$ Bezdek et al. ${ }^{30}$ and The Brookings Institution ${ }^{31}-$ would exclude what could be considered green jobs in traditional industries, such as individuals implementing energy-efficiency programs at "non-green" places of employment. This reflects the difference between the output approach compared to the process approach for defining green jobs. The output approach identifies establishments that produce green goods and services and then counts the associated jobs; the process approach identifies establishments that use environmentally friendly production processes and practices and counts the associated jobs. The output approach identifies jobs related to producing a certain set of goods and services, such as solar panels. The process approach identifies "activities and associated jobs that favorably impact the environment although the product or service produced is itself not 'green.", 32

23 M.C. Moore, J. Sharpless and M. Masri, “A Renewable Energy Resources Plan for the State of California," California Energy Commission, 1997.

${ }^{24}$ Kammen, Kapadia and Fripp, "Putting Renewables to Work."

25 Environmental Careers Organization (ECO) Canada, "Defining the Green Economy," Labour Market Research Study, 2010.

${ }^{26}$ Environmental Careers Organization (ECO) Canada, "Profile of Canadian Environmental Employment," Labour Market Research Study, 2010.

27 Environmental Careers Organization (ECO) Canada, "Defining the Green Economy."

28 OECD, "The Environmental Goods \& Services Industry."

29 Statistics Canada, "Environment Industry: Business Sector," Catalogue number 16F0008XIE, September 24, 2007, http://www5 .statcan.gc.ca/bsolc/olc-cel/olc-cel?catno=16F0008X\&lang=eng.

30 Bezdek, Wendling and DiPerna, "Environmental Protection, the Economy and Jobs."

31 Muro, Rothwell and Saha, "Sizing the Clean Economy."

32 U.S. Bureau of Labor Statistics, "Overall approach to measuring green jobs," http://www.bls.gov/green/. 
Measurement and definition of the number of green jobs in the United States by the Bureau of Labor Statistics follows the output and the process approach. This is also the most

comprehensive and data-driven, as the process approach captures occupations and jobs missed by the output approach. On the other hand, the definition used by Statistics Canada is to simply define green industries rather than green jobs - firms operating in Canada that are involved in the production of environmental goods or the provision of environmental services.

\section{TABLE 1: DEFINITIONS OF GREEN JOBS}

\begin{tabular}{|c|c|c|}
\hline Report & Definition & Notes \\
\hline Bezdek et al. ${ }^{33}$ & $\begin{array}{l}\text { "[E]nvironmental industries and green jobs [are] those which, as a result of environmental } \\
\text { pressures and concerns, have produced the development of products, processes, and } \\
\text { services, which specifically target the reduction of environmental impact. Environment- } \\
\text { related jobs include those created both directly and indirectly by EP expenditures." }\end{array}$ & $\begin{array}{l}\text { Defines U.S. } \\
\text { "environmental } \\
\text { jobs" }\end{array}$ \\
\hline Global Insight ${ }^{34}$ & $\begin{array}{l}\text { "[A]ny activity that generates electricity using renewable or nuclear fuels, agriculture jobs } \\
\text { supplying corn or soy for transportation fuel, manufacturing jobs producing goods used in } \\
\text { renewable power generation, equipment dealers and wholesalers specializing in renewable } \\
\text { energy or energy-efficiency products, construction and installation of energy and pollution } \\
\text { management systems, government administration of environmental programs, and } \\
\text { supporting jobs in the engineering, legal, research and consulting fields." }\end{array}$ & $\begin{array}{l}\text { Defines green } \\
\text { jobs }\end{array}$ \\
\hline Renner et al. ${ }^{35}$ & $\begin{array}{l}\text { "[E]mployment that contributes to preserving or restoring environmental quality and } \\
\text { avoiding future damage to Earth's ecosystems." }\end{array}$ & $\begin{array}{l}\text { Defines green } \\
\text { jobs }\end{array}$ \\
\hline Worldwatch ${ }^{36}$ & $\begin{array}{l}\text { "[P]ositions in agriculture, manufacturing, construction, installation, and maintenance, as } \\
\text { well as scientific and technical, administrative, and service-related activities, that contribute } \\
\text { substantially to preserving or restoring environmental quality. Specifically, but not } \\
\text { exclusively, this includes jobs that help to protect and restore ecosystems and biodiversity; } \\
\text { reduce energy, materials, and water consumption through high-efficiency and avoidance } \\
\text { strategies; decarbonizes the economy; and minimize or altogether avoid generation of all } \\
\text { forms of waste and pollution." }\end{array}$ & $\begin{array}{l}\text { Defines green } \\
\text { jobs }\end{array}$ \\
\hline $\begin{array}{l}\text { Bezdek/ American } \\
\text { Solar Energy } \\
\text { Society }{ }^{37}\end{array}$ & $\begin{array}{l}\text { "A job in the RE [renewable energy] industry consists of an employee working in one of the } \\
\text { major RE technologies - wind, photovoltaics, solar thermal, hydroelectric power, geothermal, } \\
\text { biomass (ethanol, biodiesel, and biomass power), and fuel cells and hydrogen. A job in the } \\
\text { EE [energy efficiency] industry consists of an employee working in a sector that is entirely } \\
\text { part of the EE industry, such as an energy service company or the recycling, reuse, and } \\
\text { remanufacturing sector. It also includes some employees in industries in which only a } \\
\text { portion of the output is classified as within the EE sector, such as household appliances, } \\
\text { HVAC systems, construction, automobile manufacturing, and others. Jobs in RE\&EE include } \\
\text { persons involved in RE\&EE activities in federal, state, and local government, universities, } \\
\text { nonprofits, trade and professional associations, non-governmental organizations, } \\
\text { foundations, consultancies, investment companies, and other related organizations." }\end{array}$ & $\begin{array}{l}\text { Defines } \\
\text { renewable- } \\
\text { energy and } \\
\text { energy-efficiency } \\
\text { jobs }\end{array}$ \\
\hline $\begin{array}{l}\text { Michigan Green } \\
\text { Jobs Report }{ }^{38}\end{array}$ & $\begin{array}{l}\text { "Includes primary occupations engaged in generating a firm's green-related products or } \\
\text { services, and the other support jobs created by the firm's green-related revenue." }\end{array}$ & $\begin{array}{l}\text { Defines green } \\
\text { jobs }\end{array}$ \\
\hline
\end{tabular}

33 Bezdek, Wendling and DiPerna, "Environmental Protection, the Economy and Jobs."

34 Global Insight, "U.S. Metro Economics."

35 Renner, Sweeney and Kubit, "Green Jobs: Working for People and the Environment."

36 UNEP/ILO/IOE/ITUC, “Green Jobs: Towards Decent Work in a Sustainable, Low-Carbon World.”

37 Roger H. Bezdek, "Green Collar Jobs in the U.S. and Colorado: Economic Drivers for the 21st Century," American Solar Energy Society Report, January 2009.

38 Bruce Weaver et al., "Michigan Green Jobs Report 2009: Occupations \& Employment in the New Green Economy," Michigan Department of Energy, Labor and Economic Growth: Bureau of Labor Market Information \& Strategic Initiatives, May 2009, http://www.michigan.gov/documents/nwlb/GJC_GreenReport_Print_277833_7.pdf. 


\section{TABLE 1: DEFINITIONS OF GREEN JOBS (cont'd)}

\begin{tabular}{|l|l|l|}
\hline Report & Definition & Notes \\
\hline ECO Canada ${ }^{39}$ & $\begin{array}{l}\text { "[0]ne that works directly with information, technologies, or materials that minimize } \\
\text { environmental impact, and also requires specialized skills, knowledge, training, or } \\
\text { experience related to these areas." }\end{array}$ & $\begin{array}{l}\text { Defines green } \\
\text { jobs }\end{array}$ \\
\hline $\begin{array}{l}\text { Martinez- } \\
\text { Fernandez et al. }{ }^{40}\end{array}$ & $\begin{array}{l}\text { "[J]obs that contribute to protecting the environment and reducing the harmful effects } \\
\text { human activity has on it (mitigation), or to helping to better cope with current climate } \\
\text { change conditions (adaptation)." }\end{array}$ & $\begin{array}{l}\text { Defines green } \\
\text { jobs }\end{array}$ \\
\hline $\begin{array}{l}\text { U.S. Bureau of } \\
\text { Labor Statistics }\end{array}$ & $\begin{array}{l}\text { A. Jobs in businesses that produce goods or provide services that benefit the environment } \\
\text { or conserve natural resources. } \\
\text { B. Jobs in which workers' duties involve making their establishment's production processes } \\
\text { more environmentally friendly or use fewer natural resources }\end{array}$ & $\begin{array}{l}\text { Defines green } \\
\text { jobs }\end{array}$ \\
\hline
\end{tabular}

\section{TABLE 2: DEFINITIONS OF THE GREEN INDUSTRY/ECONOMY}

\begin{tabular}{|c|c|c|}
\hline Report & Definition & Notes \\
\hline $0 \mathrm{ECD}^{42}$ & $\begin{array}{l}\text { "[C]onsists of activities which produce goods and services to measure, prevent, limit, } \\
\text { minimise or correct environmental damage to water, air and soil, as well as problems } \\
\text { related to waste, noise and eco-systems. This includes cleaner technologies, products and } \\
\text { services that reduce environmental risk and minimise pollution and resource use." }\end{array}$ & $\begin{array}{l}\text { Classifies the } \\
\text { environmental } \\
\text { goods and } \\
\text { services industry }\end{array}$ \\
\hline Statistics Canada ${ }^{43}$ & $\begin{array}{l}\text { "[A]\|l firms operating in Canada that are involved, in whole or in part, in the production of } \\
\text { environmental goods (including construction) or the provision of environmental services." }\end{array}$ & $\begin{array}{l}\text { Defines the } \\
\text { environment } \\
\text { industry }\end{array}$ \\
\hline ECO Canada ${ }^{44}$ & $\begin{array}{l}\text { "The aggregate of all activity operating with the primary intention of reducing conventional } \\
\text { levels of resource consumption, harmful emissions, and minimizing all forms of } \\
\text { environmental impact. The green economy includes the inputs, activities, outputs and } \\
\text { outcomes as they relate to the production of green products and services." }\end{array}$ & $\begin{array}{l}\text { Defines the green } \\
\text { economy }\end{array}$ \\
\hline Eurostat ${ }^{45}$ & $\begin{array}{l}\text { "[A] heterogeneous set of producers of technologies, goods and services that: } \\
\text { Measure, control, restore, prevent, treat, minimise, research and sensitise environmental } \\
\text { damages to air, water and soil as well as problems related to waste, noise, biodiversity } \\
\text { and landscapes. This includes 'cleaner' technologies, goods and services that prevent or } \\
\text { minimise pollution. } \\
\text { Measure, control, restore, prevent, minimise, research and sensitise resource depletion. } \\
\text { This results mainly in resource-efficient technologies, goods and services that minimise } \\
\text { the use of natural resources. } \\
\text { These technologies and products (i.e. goods and services) must satisfy the end purpose } \\
\text { criterion, i.e. they must have an environmental protection or resource management purpose } \\
\text { (hereinafter 'environmental purpose') as their prime objective." }\end{array}$ & $\begin{array}{l}\text { Defines the } \\
\text { environmental } \\
\text { goods and } \\
\text { services sector }\end{array}$ \\
\hline
\end{tabular}

39 Environmental Careers Organization (ECO) Canada, "Defining the Green Economy."

40 Cristina Martinez-Fernandez, Carlos Hinojosa and Gabriela Miranda, "Greening Jobs and Skills: Labour Market Implications of Addressing Climate Change," OECD Local Economic and Employment Development (LEED) Working Paper, 2010.

${ }^{41}$ U.S. Bureau of Labor Statistics, "Overall approach to measuring green jobs."

42 OECD, "The Environmental Goods \& Services Industry: Manual for Data Collection and Analysis."

43 Statistics Canada, "Environment Industry: Business Sector."

44 Environmental Careers Organization (ECO) Canada, "Defining the Green Economy."

45 Eurostat, "The environmental goods and services sector - a data collection handbook." 


\section{TABLE 2: DEFINITIONS OF THE GREEN INDUSTRY/ECONOMY (cont'd)}

\begin{tabular}{|l|l|l|}
\hline Report & Definition & Notes \\
\hline $\begin{array}{l}\text { Michigan Green } \\
\text { Jobs Report }\end{array}$ & $\begin{array}{l}\text { “Industries that provide products or services related to renewable energy, increased energy } \\
\text { efficiency, clean transportation and fuels, agriculture and natural resource conservation, and } \\
\text { pollution prevention or environmental cleanup." }\end{array}$ & $\begin{array}{l}\text { Defines the green } \\
\text { economy }\end{array}$ \\
\hline $\begin{array}{l}\text { The Pew Charitable } \\
\text { Trusts }\end{array}$ & $\begin{array}{l}\text { "A clean energy economy generates jobs, businesses and investments while expanding } \\
\text { clean energy production, increasing energy efficiency, reducing greenhouse gas emissions, } \\
\text { waste and pollution, and conserving water and other natural resources. } \\
\text { The clean energy economy cuts across five categories: (1) Clean Energy; (2) Energy } \\
\text { Efficiency; (3) Environmentally Friendly Production; (4) Conservation and Pollution } \\
\text { Mitigation; and (5) Training and Support." }\end{array}$ & $\begin{array}{l}\text { "clean energy } \\
\text { economy" in the } \\
\text { U.S. }\end{array}$ \\
\hline ECO Canada & $\begin{array}{l}\text { "[E]mployed individuals who spend 50\% or more of their work time on activities associated } \\
\text { with environmental protection, resource management, or environmental sustainability." }\end{array}$ & $\begin{array}{l}\text { Defines Canadian } \\
\text { environmental } \\
\text { employment }\end{array}$ \\
\hline
\end{tabular}

\section{Critiques of the Green-Jobs Literature}

Many of the studies counting green jobs or predicting future green jobs argue that investing in green activities will result in employment (and economic) growth. A commonly promoted green activity is switching to a higher share of electricity produced from renewable sources. ${ }^{49}$ Others concentrate on reducing transportation and switching to local agriculture. ${ }^{50}$ Many of these studies have been criticized on the basis of their methodology as well as the conclusions reached. We provide a brief overview of the critiques below.

Job Creation as a Goal: One of the most common critiques is focused on the nature of green jobs where their creation and/or existence is considered to be a benefit and rationale for proposed programs. Tuerck et al. note that green-job studies suggest that the benefit of requiring more "green" work to create the same amount of energy or output counts as a benefit. ${ }^{5 l}$ Indeed, ClearSky Advisors, ${ }^{52}$ Worldwatch, ${ }^{53}$ the Union of Concerned Scientists, ${ }^{54}$ and Greenpeace ${ }^{55}$

46 Bruce Weaver et al., "Michigan Green Jobs Report 2009."

47 The Pew Charitable Trusts, "The Clean Energy Economy."

48 Environmental Careers Organization (ECO) Canada, "Profile of Canadian Environmental Employment."

49 Pollin et al., "Green Recovery: A Program to Create Good Jobs and Start Building a Low-Carbon Economy"; Muro, Rothwell and Saha, "Sizing the Clean Economy"; Rutovitz and Atherton, "Energy sector jobs to 2030: a global analysis."

${ }^{50}$ UNEP/ILO/IOE/ITUC, "Green Jobs: Towards Decent Work in a Sustainable, Low-Carbon World”; Renner, Sweeney and Kubit, "Green Jobs: Working for People and the Environment."

51 David G. Tuerck, Benjamin Powell and Paul Bachman, “'Green Collar’ Job Creation: A Critical Analysis,” Beacon Hill Institute Policy Study No. 52, June 2009, http://www.beaconhill.org/BHIStudies/GreenJobs09/BHIGreen_Collar_Job_Critique090625.pdf.

52 ClearSky Advisors, “The Economic Impacts of the Wind Energy Sector in Ontario 2011-2018," Report Commissioned by the Canadian Wind Energy Association, 2011, http://www.canwea.ca/pdf/economic_impacts_wind_energy_ontario2011-2018.pdf.

53 UNEP/ILO/IOE/ITUC, "Green Jobs: Towards Decent Work in a Sustainable, Low-Carbon World."

54 Union of Concerned Scientists, “Clean Energy, Green Jobs” Fact Sheet, 2009, http://www.ucsusa.org/clean_energy/smart-energy-solutions/increase-renewables/clean-energy-green-jobs.html.

55 Rutovitz and Atherton, "Energy sector jobs to 2030: a global analysis." 
embrace this notion. Morriss et al. ${ }^{56}$ note the green-jobs estimates from the literature often include clerical, bureaucratic and/or administrative positions. Gülen, ${ }^{57}$ Michaels and Murphy, ${ }^{58}$ and Morriss et al..$^{59}$ argue that by promoting more jobs instead of productivity, proponents of green jobs are encouraging inefficient use of labour.

The appropriate measure of "success" is when a green-job program creates more jobs than any alternative use, including lower tax burdens overall. Again, this metric is not always used, as many studies chose to evaluate programs based on jobs per unit of energy produced. The second measure of success, jobs per unit of energy produced, is difficult to justify and measure. Energy is the output, and labour, or jobs, is one of the inputs. Traditional measures of productivity are output per unit of input, and measuring jobs per unit of energy is simply the inverse of the program's or industry's labour productivity. Based on this understanding of the relationship between productivity and jobs, programs that create more jobs per unit of energy produced are inefficient and waste resources. Using this measure as a way to judge the success of policies rewards inefficiency.

Failure to Consider Net Effects: Some but not all green job studies consider job creation but not destruction, and create an overly simplistic view of the labour market. ${ }^{60}$ Tuerck et al. argue that green jobs can be considered net benefits only if the value the job produces is greater than the cost of performing the job, and note that most green-jobs studies fail to make this argument. ${ }^{6 l}$ There is little acknowledgement of part-time green jobs, and often existing jobs that are considered green are counted as "new." Gülen ${ }^{62}$ notes a common issue with green-jobs reports is that the quoted number of jobs created does not distinguish between (temporary) construction jobs and (long-term) operational jobs. ${ }^{63}$ Moreover, increased energy costs as a result of many promoted policies can lead to job losses in other sectors such as environmental remediation or construction.

56 Andrew P. Morriss, William T. Bogart, Andrew Dorchak and Roger E. Meiners, "Seven Myths About Green Jobs," International Policy Network Working Paper, 2010.

57 Gürcan Gülen, "Defining, Measuring and Predicting Green Jobs," Copenhagen Consensus Center Research Paper, February 2011, http://www.copenhagenconsensus.com/research/climate-change-and-energy/economic-analysis-ofthe-promise-of-green-jobs.

58 Robert Michaels and Robert Murphy, "Green Jobs: Fact or Fiction? An Assessment of the Literature," Institute for Energy Research Report, 2009, http://www.instituteforenergyresearch.org/2009/01/13/green-jobs-analysis/.

59 Morriss et al., "Seven Myths About Green Jobs."

60 See: Gülen, "Defining, Measuring and Predicting Green Jobs"; and Michaels and Murphy, "Green Jobs: Fact or Fiction?", for further details on this issue.

61 Tuerck, Powell and Bachman, “'Green Collar' Job Creation.”

62 Gülen, "Defining, Measuring and Predicting Green Jobs."

63 This is a problem endemic to many job creation programs, not just green jobs. An example of this is estimates of job creation from Canada's Economic Action Plan (Table A2.16 in "The Stimulus Phase of Canada's Economic Action Plan: A Final Report to Canadians"). 
Costs of Investment: The incentive for, and the investment commitment to, develop new energy capacity is often assumed by policy-makers, but rarely justified. Gülen notes that many positive effects associated with these programs depend on aggressive growth assumptions for renewable power. ${ }^{64}$ Michaels and Murphy identify a common assumption that holds that the potential benefits from new technologies will occur only through government programs, ignoring the role of the private sector in investment and job creation. ${ }^{65}$ Gülen makes the further point that the technical challenge of creating infrastructure to handle large amounts of intermittent electricity supply is not addressed.

Role of Trade: Morriss et al. note that the green-jobs literature typically encourages reducing trade and relying on local production, stating "this is a recipe for economic disaster." ${ }^{16}$ Gülen supports this by stating that many studies rely on protectionist policies to support local industries. He notes that government support (tax breaks, subsidies, domestic content requirement, etc.) of green projects distort "comparative cost advantages and often lead to adoption of more expensive technologies." While not a critique of the green-jobs literature per se, Lehr et al. observe that an increase in net employment depends heavily on the continued ability of a country, such as Germany, to export renewable energy. ${ }^{67}$

Limiting Competition: The Task Force on Competitiveness, Productivity and Economic Progress suggests Ontario's Feed-in-Tariff (FIT) system can inhibit innovation by encouraging electricity producers to lock into existing technologies in order to gain the system's subsidies. ${ }^{68}$ For instance, the report notes that solar power and wind power are heavily subsidized through the FIT program, and states that it is not clear if these technologies are the best method of reducing carbon emissions in a cost-effective manner. The report suggests that instead of trying to pick winning technologies, the Ontario government should adopt "winner-neutral" policies, such as carbon pricing.

In addition to critiquing the green-jobs literature, Michaels and Murphy offer questions they feel the literature has failed to ask. ${ }^{69}$ How much government support of "green" markets is enough? Are the programs sustainable? Hughes ${ }^{70}$ raises three questions that should be addressed when considering job creation linked to policies for promoting renewable energy,

${ }^{64}$ Gülen, "Defining, Measuring and Predicting Green Jobs."

65 Michaels and Murphy, "Green Jobs: Fact or Fiction?"

${ }^{66}$ Most economists would undoubtedly agree there are (significant) productivity increases due to trade, and that restricting trade will have negative effects on output. However, as Costas Arkolakis, Arnaud Costinot and Andrés Rodríguez-Clare show, little is known about the true magnitude of gains from trade. ("New Trade Models, Same Old Gains?" American Economic Review 102, 1: 94-130 (February 2012)).

67 Ulrike Lehr, Christian Lutz and Dietmar Edler, "Green Jobs? Economic Impacts of Renewable Energy in Germany," Energy Policy 47, 1 (2012) 358-364 ; Ulrike Lehr et al., "Renewable Energy and Employment in Germany," Energy Policy 36, 1 (2008) 108-117.

68 Task Force on Competitiveness, Productivity and Economic Progress, "Today's innovation, tomorrow's prosperity," Ninth Annual Report, November 2010.

69 Michaels and Murphy, "Green Jobs: Fact or Fiction?"

70 Gordon Hughes, "The Myth of Green Jobs," The Global Warming Policy Foundation, GWPF Report 3, 2011, http://thegwpf.org/images/stories/gwpf-reports/hughes-green_jobs.pdf. 
energy conservation or reducing emissions: 1) Why would, or should, the creation of jobs be seen as a reasonable basis for assessing the merits of economic or environmental policies? 2) If job creation is a relevant basis for assessing the potential impact of environmental policies, are there sound reasons to believe that green-energy policies can lead to an increase in the total level of employment? 3) Is there any convincing evidence that the green-energy policies being implemented will actually lead to higher levels of total employment, either in the short term or long run?

\section{Green Jobs in Canada}

There is little information on green employment in Canada. As many studies point out, green jobs do not typically fit into standard industry or occupational definitions. As noted by Statistics Canada, "The environment industry is not a traditional industry sector and is not currently defined in the North American Classification of Industries System (NAICS)." Statistics Canada surveys the environment industry, but does not attempt to count green jobs. ECO Canada surveyed employment at "green companies" and Canadian environmental employment. Beyond Statistics Canada and ECO Canada, other estimates of green jobs are from research papers looking at specific programs, and not a broad analysis of green employment.

\section{PREVIOUS ESTIMATES}

Statistics Canada performs a biennial survey of the environment industry and reports on its activities, but the latest report available, published in 2007, details results from a survey that occurred in 2004. The survey has employment statistics for environmental establishments, which are defined as establishments that earned revenues from the sale of environmental goods or services. These are reported in Table 3, below. Unfortunately, the 2007 report does not give environmental employment as a percentage of total employment in the industries identified, only environmental employment as a percentage of total employment at the environmental establishments.

\footnotetext{
71 Rowena Orok, "Measuring Employment in the Environment Industry," Statistics Canada Environmental Accounts and Statistics Technical Paper Series, Catalogue Number 16-001-MIE, 001, 2004, http://www5.statcan.gc.ca/bsolc/olc-cel/olc-cel?catno=16-001-M2004001\&lang=eng.
} 
TABLE 3: EMPLOYMENT IN ENVIRONMENTAL ESTABLISHMENTS, 2004

\begin{tabular}{|c|c|}
\hline $\begin{array}{l}\text { Industry groups that include environmental } \\
\text { establishments }\end{array}$ & $\begin{array}{l}\text { Environmental employees as a } \\
\text { percentage of total employees }\end{array}$ \\
\hline Agriculture, forestry, fishing and hunting & 42 \\
\hline Mining and oil and gas extraction & 42 \\
\hline Utilities & 5 \\
\hline Construction & 22 \\
\hline Chemical manufacturing & 22 \\
\hline Plastic and rubber products manufacturing & 44 \\
\hline Non-metallic mineral product manufacturing & 24 \\
\hline Primary metal manufacturing & 31 \\
\hline Fabricated metal product manufacturing & 26 \\
\hline Machinery manufacturing & 41 \\
\hline Computer and electronic product manufacturing & 41 \\
\hline Electrical equipment, appliance and component manufacturing & 55 \\
\hline Other manufacturing & 45 \\
\hline Wholesale trade & 21 \\
\hline Retail trade & 52 \\
\hline Finance and insurance services & 6 \\
\hline Legal services & 4 \\
\hline Architectural and landscape architectural services & 24 \\
\hline Engineering services & 27 \\
\hline Surveying and mapping (including geophysical) services & 18 \\
\hline Testing laboratories & 47 \\
\hline Computer systems design and related services & 10 \\
\hline Environmental consulting services & 59 \\
\hline Management consulting and other scientific and technical consulting services & 48 \\
\hline Scientific research and development services & 70 \\
\hline All other professional, scientific and technical services & 21 \\
\hline Management of companies and enterprises & 23 \\
\hline Administrative and support services & 39 \\
\hline Waste management and remediation services & 67 \\
\hline Other services & 21 \\
\hline
\end{tabular}

Source: Statistics Canada, “Environment Industry: Business Sector,” Table A.19.1.

A 2004 working paper from Statistics Canada makes the distinction between environmental employment and employment in environmental industries, and outlines different methodologies to estimate environmental employment. Previous Statistics Canada publications on the environmental sector reported total employment in identified establishments. Table 3 reflects the attempt to account for environmental employment in the identified establishments.

An estimate of total employment in environmental industries from Statistics Canada necessitates using data from 2000, reflecting the shift to reporting environmental employment, as we point out above. Moreover, due to the way environmental industries are constructed by 
the Environmental Accounts Division, environmental employment as a percentage of total employment by industry group is not always possible to calculate. ${ }^{72}$ Finally, due to the age of the data, the Statistics Canada reports do not provide much information about green employment in Canada.

More recently, ECO Canada surveyed 501 "green companies" in Canada. ${ }^{73}$ Based on the survey, ECO finds that many green companies (43 per cent) were primarily involved in professional, scientific and professional services. It also found that 66 per cent of green companies reported more than 50 per cent of full-time employees worked in green jobs some or all of the time. A survey of Canadian environmental employment by ECO Canada ${ }^{74}$ estimates that Canada has over 682,000 environmental employees. Based on this, ECO Canada concludes that four per cent of the total (employed) Canadian labour force is engaged in

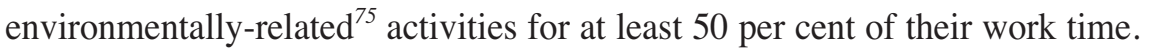

Table 4 replicates the results from the ECO Canada survey, displaying the distribution of Canadian environmental employees by two-digit NAICS code. It is noteworthy that the industry with the largest number of workers identified as environmental employees -17.8 per cent of Canadian environmental employment - falls under the category "Education, Health and Social Assistance." This is interesting, as the majority of industry groups identified by Statistics Canada as part of the environmental industry fall under manufacturing, professional services, and primary industries.

Based on the "50 per cent of time spent on environmental activities" measure of green employment, the "greenest" industry category in Canada, with the highest proportion of the workforce in environmental employment, is Agriculture, Forestry, Fishing and Hunting. Using the lenient measure of some amount of time spent on environmental activities, the greenest industry category by proportion of workers is Arts, Recreation, Accommodation and Food Services. Looking at total number of employees, the greenest industry category is Wholesale and Retail Trade.

\footnotetext{
72 Many of the environmental-services industry groups are based on four- or five-digit NAICS codes, and total employment detail is not available at this level.

73 Environmental Careers Organization (ECO) Canada, "Defining the Green Economy."

74 Environmental Careers Organization (ECO) Canada, "Profile of Canadian Environmental Employment."

75 Environmental employment is defined in the ECO Canada study as "employed individuals who spend 50\% or more of their work time on activities associated with environmental protection, resource management, or environmental sustainability."
} 
TABLE 4: TOTAL CANADIAN ENVIRONMENTAL EMPLOYEES BY INDUSTRY

\begin{tabular}{|c|c|c|c|c|c|}
\hline \multirow[t]{3}{*}{ Province } & \multicolumn{4}{|c|}{ Environmental Employees } & \multirow{3}{*}{$\begin{array}{l}\text { Total Canadian } \\
\text { Employment } \\
\text { (March 2009) }\end{array}$} \\
\hline & \multicolumn{2}{|c|}{$\begin{array}{l}\text { Spending more than } 50 \text { per cent of } \\
\text { their time on environmental activities }\end{array}$} & \multicolumn{2}{|c|}{$\begin{array}{l}\text { Spending any time on } \\
\text { environmental activities }\end{array}$} & \\
\hline & Workers & $\begin{array}{c}\% \text { of } \\
\text { workforce }\end{array}$ & Workers & $\begin{array}{c}\% \text { of } \\
\text { workforce }\end{array}$ & \\
\hline $\begin{array}{l}\text { Agriculture, Forestry, } \\
\text { Fishing and Hunting }\end{array}$ & 41,878 & 10.8 & 64,019 & 16.4 & 389,528 \\
\hline $\begin{array}{l}\text { Mining, Quarrying, and } \\
\text { Oil and Gas Extraction }\end{array}$ & 11,405 & 4.5 & 22,868 & 9.1 & 251,972 \\
\hline Construction & 89,020 & 7.4 & 213,783 & 17.9 & $1,195,900$ \\
\hline Manufacturing & 71,934 & 4.1 & 252,565 & 14.3 & $1,767,700$ \\
\hline Wholesale and Retail Trade & 93,265 & 3.5 & 441,853 & 16.6 & $2,657,600$ \\
\hline $\begin{array}{l}\text { Utilities, Transportation } \\
\text { and Warehousing }\end{array}$ & 18,544 & 2.0 & 69,486 & 7.5 & 928,400 \\
\hline $\begin{array}{l}\text { Information, Finance and } \\
\text { Insurance, Real Estate and } \\
\text { Management of Companies }\end{array}$ & 7,340 & 0.5 & 34,773 & 2.3 & $1,516,442$ \\
\hline $\begin{array}{l}\text { Professional, Scientific and } \\
\text { Technical Services }\end{array}$ & 65,285 & 5.1 & 127,377 & 10.0 & $1,276,450$ \\
\hline $\begin{array}{l}\text { Administration and Support, } \\
\text { Waste Management and } \\
\text { Remediation }\end{array}$ & 36,124 & 5.8 & 96,105 & 15.4 & 624,854 \\
\hline $\begin{array}{l}\text { Education, Health and } \\
\text { Social Assistance }\end{array}$ & 121,751 & 3.7 & 268,755 & 8.3 & $3,246,900$ \\
\hline $\begin{array}{l}\text { Arts, Recreation, } \\
\text { Accommodation and } \\
\text { Food Services }\end{array}$ & 59,252 & 4.1 & 280,714 & 19.5 & $1,436,593$ \\
\hline Other Services & 20,913 & 2.9 & 99,079 & 13.6 & 731,000 \\
\hline Public Administration & 45,578 & 4.8 & 100,609 & 10.7 & 939,865 \\
\hline Total & 682,289 & 4.0 & $2,071,985$ & 12.2 & $16,963,204$ \\
\hline
\end{tabular}

Source: Environmental Careers Organization (ECO) Canada, "Profile of Canadian Environmental Employment," Table 1.

Figure 1 displays environmental employment by occupational area, as identified by ECO Canada. The largest category is "Environmental Safety and Health," with 40 per cent of environmental employment, followed by "Waste Management" (28 per cent). It is interesting to note that "Environmental Communication and Public Awareness," at 19 per cent, has almost the same number of workers as "Site Assessment and Reclamation" (20 per cent). This speaks to the importance of public awareness and support within the green or environmental industry as a whole. 
FIGURE 1: ENVIRONMENTAL EMPLOYEES BY OCCUPATIONAL AREAS ${ }^{76}$

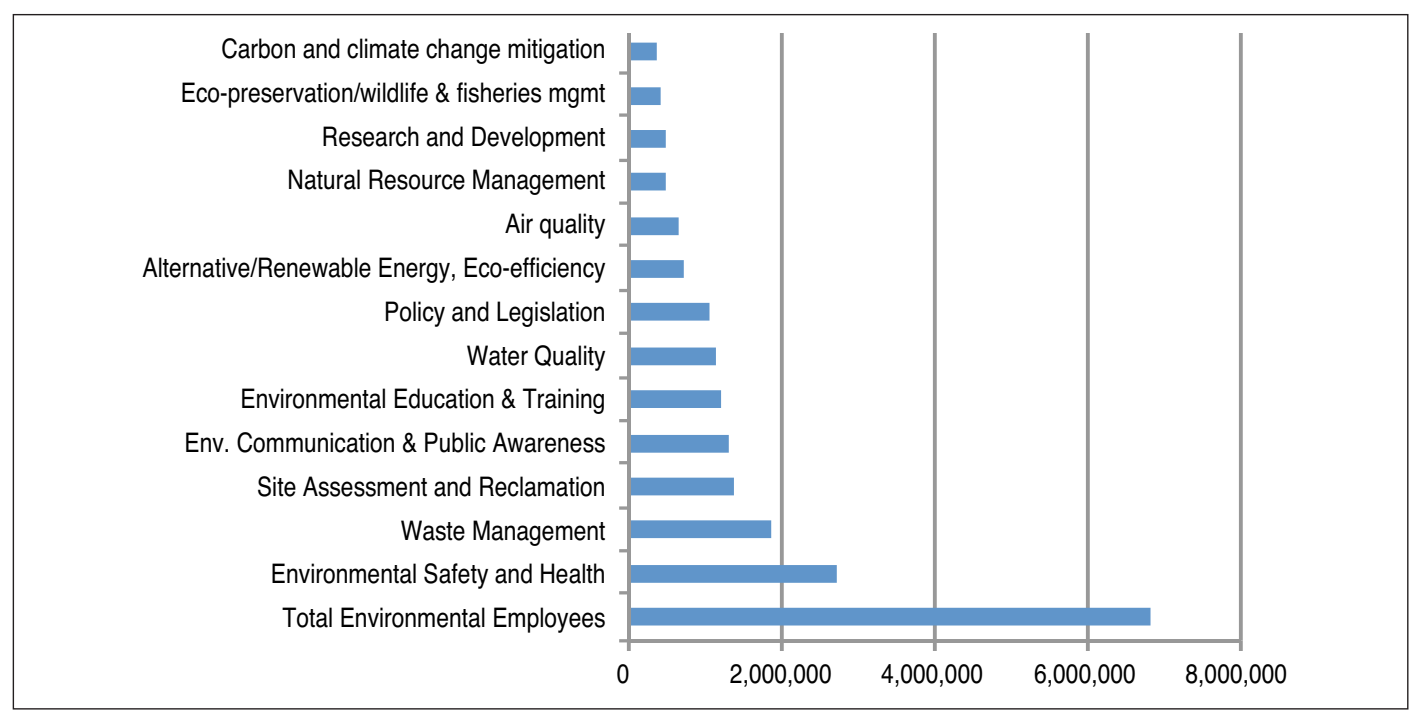

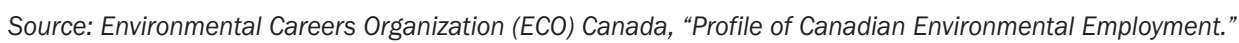

Table 5 and Figure 2 provide the distribution of environmental employment by province in Canada. We can see that the proportion of environmental employment to total workers in each province/region is relatively proportional to the size of the labour force. Environmental employment is highest in Ontario and Quebec, reflecting their larger populations and larger labour force.

\section{TABLE 5: ENVIRONMENTAL EMPLOYEES BY PROVINCE}

\begin{tabular}{|l|c|c|c|c|}
\hline Province & $\begin{array}{c}\text { Environmental } \\
\text { Employees }\end{array}$ & $\begin{array}{c}\text { Total Employment } \\
\text { March 2010 }\end{array}$ & $\begin{array}{c}\text { Share of } \\
\text { Environmental } \\
\text { Employment }\end{array}$ & $\begin{array}{c}\text { Environmental } \\
\text { Employees as a } \\
\text { Percentage of } \\
\text { Workers in Province }\end{array}$ \\
\hline Atlantic Provinces & 46,847 & $1,099,199$ & 6.9 & 4.3 \\
Quebec & 155,504 & $3,877,644$ & 22.8 & 4.0 \\
Ontario & 253,552 & $6,595,121$ & 37.2 & 3.8 \\
Manitoba \& Saskatchewan & 48,771 & $1,140,680$ & 7.1 & 4.3 \\
Alberta & 83,956 & $1,982,121$ & 12.3 & 4.2 \\
British Columbia & 92,739 & $2,268,499$ & 13.6 & 4.1 \\
Canada Total & 682,289 & $16,963,204$ & 100 & 4.0 \\
\hline
\end{tabular}

76 According to ECO Canada, as "most environmental employers indicated that their employees performed activities in more than one NOS category, the total [exceeds]100\%." 
FIGURE 2: ENVIRONMENTAL EMPLOYMENT SHARES BY PROVINCE

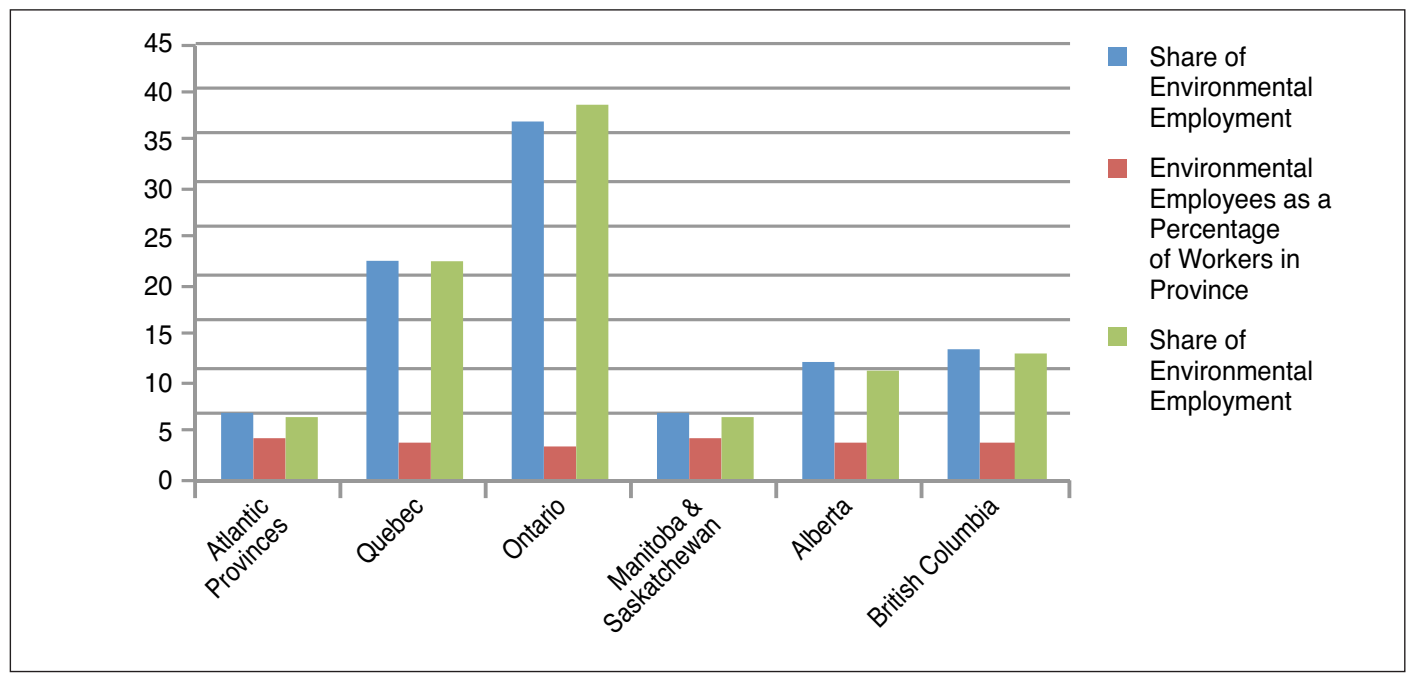

Beyond estimates by Statistics Canada and ECO Canada, most green-job counting in Canada appears to have been focused on programs in Ontario. The Ontario government estimates that its provincial renewable-energy program created 50,000 jobs. A C.D. Howe Institute e-brief on the program discusses two potential issues with the government's job-creation estimate of 50,000 jobs. ${ }^{77}$ The authors argue the majority of jobs in construction, manufacturing and spinoff industries would have existed in the absence of the Ontario government's subsidies. Moreover, higher electricity costs as a result of the renewable-energy program will raise business costs, resulting in fewer jobs than would exist in the absence of the program. The authors argue that the net number of jobs could even be negative.

Bohringer et al. also evaluate Ontario's FIT program and find that, although the policy is successful at increasing employment in the "green" sectors of the economy, the policy is also likely to increase the rate of unemployment in the province, and to reduce overall labour-force participation. ${ }^{78}$ They estimate green employment increased by 11,000 jobs, but that 1.97 jobs were lost in other sectors for every green job gained.

A recent study by the Conference Board of Canada on Ontario's offshore wind industry suggests that the industry would generate between 55,000 and 62,000 person-years of employment from 2013 to $2026 .{ }^{79}$ In both cases, approximately 52 per cent of the new employment would be in services; while in the best-case scenario for job creation, only seven per cent of person-years would be associated with permanent operations and maintenance of facilities. Considering the entire Ontario wind industry, ClearSky Advisors estimate 80,000 person-years of employment will be generated between 2011 and $2018 .{ }^{80}$ However, only 1,031 permanent operation and maintenance jobs are estimated.

77 Benjamin Dachis and Jan Carr, "Zapped: The High Cost of Ontario's Renewable Electricity Subsidies,” C.D. Howe Institute e-brief 117, May 31, 2011.

78 Christoph Bohringer, Nicholas J. Rivers, Thomas F. Rutherford and Randall Wigle, "Green jobs and renewable energy policies: Employment impacts of Ontario's feed-in tariff," Berkeley Electronic Journal of Economic Analysis and Policy (Contributions) 12, 1 (2012) 1-38.

79 Len Coad and Pedro Antunes, "Employment and Economic Impacts of Ontario's Future Offshore Wind Power Industry," The Conference Board of Canada Report 11-148, December 2010.

80 ClearSky Advisors, “The Economic Impacts of the Wind Energy Sector in Ontario 2011-2018." 


\section{COSTS OF GREEN-JOB CREATION}

Any government grant, subsidy or tax-relief program comes at a cost, both in terms of the government revenue spent, and the opportunity cost of the public funds. A "green jobs" or "green energy" program is no different. While it may be difficult to measure the opportunity cost of public funds spent on a specific program, the cost per job of "green" programs is relatively easy to calculate. It provides a rough measure of the effectiveness of programs in creating jobs, though it does not evaluate the effectiveness of green programs in reaching other goals (such as emission reductions). There are several studies identifying these costs in Canada, the United States and several European countries, and a brief review of these reveals the lack of consensus and metrics that show the full costs of green job programs.

Dunkley compares productivity, labour costs and subsidies in the renewable-energy sector to the petroleum sector in the United States ${ }^{81}$ Labour costs were over twice as much per barrelof-oil-equivalent for the renewable sector in 2007 , and this difference is projected to increase to over six times as much by 2020. Dunkley estimates the cost per green job from 2009-2020 in the United States to be $\$ 418,800$.

In contrast, evaluation of the Section 1603 Treasury Grant Program in the U.S. reveals a much higher cost per job, and also substantial variation in the job-creation estimates. The 1603 program was a cash grant given to renewable-technology developers in lieu of the Section 48 Investment Tax Credit. Steinberg et al. evaluate the 1603 Program and find that, as of Nov. 10, 2011 , the grant program had provided $\$ 9.7$ billion in payments for 24,711 projects.$^{82}$ Estimates of direct construction jobs were 9,400 per year, and indirect jobs were estimated between 43,000 and 66,000 per year. Operational period direct jobs were estimated at 910 per year, with between 4,200 and 4,600 indirect jobs. The operational period jobs were assumed to be sustained over the 20-to-30-year lifetime of the projects. Preliminary analysis of the 1603 program by Bolinger et al. estimated that 71 projects resulted in 74,000 gross direct and indirect jobs during the construction phase and approximately 3,900 jobs annually during the operational phase..$^{83}$ A significant caveat that Steinberg et al. place on their analysis is that the results cannot be attributed to the 1603 grant alone, as some projects "may have progressed without the award ... therefore, the jobs and economic impact estimates can only be attributed to the total investment in the projects."

With this in mind, the cost per permanent job from the grant program is, in a best-case scenario, a staggering $\$ 1.76$ million per job. Considering only direct jobs (those directly attributable to the program), the total cost is $\$ 10.7$ million per job. Including the constructionphase jobs (and not discounting by their length) brings the cost per job down to $\$ 450,953$.

\footnotetext{
${ }^{81}$ Katrina Dunkley, “The Cost of Obama's Green Dreams," Fraser Institute, Fraser Forum (March 2009) 12-15.

82 Daniel Steinberg, Gian Porro and Marshall Goldberg, "Preliminary Analysis of the Jobs and Economic Impacts of Renewable Energy Projects Supported by the $\$ 1603$ Treasury Grant Program," National Renewable Energy Laboratory Technical Report NREL/TP-6A20-52739, April 2012, http://www.nrel.gov/docs/fy12osti/52739.pdf.

83 M. Bolinger, R. Wiser and N. Darghouth, "Preliminary Evaluation of the Section 1603 Treasury Grant Program for Renewable Power Projects in the United States." Energy Policy 38 (2010) 6804-6819.
} 
Ontario boasts the most aggressive green-jobs program in Canada. Dachis and Carr evaluated Ontario's Green Energy and Green Economy Act, and using the Ontario government's estimate of 50,000 projected jobs over six years, they calculate $\$ 179,000$ in subsidies per job created. ${ }^{84}$ This is associated with a premium paid per tonne of GHG offset relative to natural-gas power generation, which they estimate at $\$ 177$ per tonne.

Also evaluating the Green Energy Act is the Ontario Task Force of Competitiveness, Productivity and Economic Progress' Ninth Annual Report. The report states the government's estimate of green jobs is unclear, as the government "has not offered a definition of green jobs nor a transparent calculation of the 50,000 result." The task force calculates the annual cost per new green job is about $\$ 42,000$. Based on a fifteen-year project lifetime, the cost per job is $\$ 630,000$.

To provide some perspective, it is useful to compare these green job costs to other subsidy programs, such as the federal Economic Action Plan. According to the Government of Canada's report on the Economic Action Plan, 248,000 jobs were created or maintained by the action plan. Table 6 displays the cost per job for different components of the plan. The job creation costs of Ontario's Green Energy Act are similar to the costs of the federal program.

\section{TABLE 6: ECONOMIC ACTION PLAN COST PER JOB}

\begin{tabular}{|l|c|c|c|}
\hline Action Plan Element & $\begin{array}{c}\text { Million Dollars } \\
\text { (March 2011) }\end{array}$ & $\begin{array}{c}\text { Jobs Created } \\
\text { or Maintained } \\
\text { (March 2011) }\end{array}$ & $\begin{array}{c}\text { Cost per Job } \\
\text { (dollars) }\end{array}$ \\
\hline Reducing the Tax Burden for Canadians & 6,288 & 24,000 & 262,000 \\
Helping the Unemployed & 8,477 & 33,000 & 256,878 \\
Building Infrastructure to Create Jobs & 21,794 & 96,000 & 227,070 \\
Advancing Canada's Knowledge & 5,463 & 28,000 & 195,107 \\
Economy and Creating Better Jobs & 18,730 & 68,000 & 275,441 \\
Supporting Industries and Communities & 60,752 & 248,000 & 244,967 \\
Total & & & \\
\hline
\end{tabular}

A CEPOS (Center for Political Studies) study evaluates the wind-powered electricity generation industry in Denmark. ${ }^{85}$ It estimates 2,800 new jobs as a result of subsidies, and a subsidy of US $\$ 90,000$ to US $\$ 140,000$ ( $\$ 102,778$ to $\$ 159,877$ in Canadian dollars) per job per year. ${ }^{86} \mathrm{In}$ addition, it calculated that reductions in carbon dioxide emissions from the wind industry are 2.4 million tons per year, with an average cost of US\$124 (\$142 Canadian) per ton. This is substantially higher than the current price for permits on the European emissions trading market.

\footnotetext{
84 Benjamin Dachis and Jan Carr, "Zapped: The High Cost of Ontario's Renewable Electricity Subsidies."

85 Center for Politiske Studier, "Wind Energy: The Case of Denmark," 2009, http://www.cepos.dk/fileadmin/user_upload/Arkiv/PDF/Wind_energy_-_the_case_of_Denmark.pdf.

${ }^{86}$ Currency conversion to Canadian dollars was using the Bank of Canada's 2009 annual average exchange rates, available at http://www.bankofcanada.ca/rates/exchange/exchange-rates-in-pdf/.
} 
Frondel et al. evaluated Germany's feed-in-tariff for renewable electricity generation, which is commonly associated with green-job creation. ${ }^{87}$ Under this system, utilities are obligated to accept the delivery of power from renewable producers, and pay a technology-specific tariff above the production cost. Frondel et al. calculate abatement costs of $€ 716(\$ 1,135)$ per ton of $\mathrm{CO}_{2}$ for photovoltaic electricity production, and $€ 54$ (\$86) per ton for wind-generated electricity. For the photovoltaic industry, based on a subsidy/net cost of $€ 8.4$ billion ( $\$ 13.3$ billion), and 48,000 workers, the cost of the feed-in-tariff program is estimated at $€ 175,000$ $(\$ 277,463)$ per worker.

Addressing the question of cost-effectiveness of green programs in terms of jobs created in the field of direct carbon dioxide management, Frondel et al. state:

"There are much cheaper ways to reduce carbon dioxide emissions than subsidizing renewable energies. $\mathrm{CO}_{2}$ abatement costs of PV are estimated to be as high as 716 $€$ (US \$1,050) per tonne, while those of wind power are estimated at $54 €$ (US $\$ 80)$ per tonne. By contrast, the current price of emissions certificates on the European emissions trading scheme is only 13.4 Euro per tonne. Hence, the cost from emission reductions as determined by the market is about 53 times cheaper than employing PV and 4 times cheaper than using wind power."

\section{IS GREEN REALLY “GREEN”?}

In spite of the myriad programs, initiatives and reports, the definition of "green job" remains elusive. The range of jobs that can be considered in this category is wide and, depending on outlook or incentive, can basically describe any job today if the qualifications are broad enough. The myriad number of definitions further complicates any classification attempt, as green jobs under one definition are "dirty" under others ${ }^{.88}$

To illustrate the point, the Worldwatch report offers this not-so-subtle distinction on green jobs, saying:

"Technological and systemic choices offer varying degrees of environmental benefit and different types of green employment. Pollution prevention has different implications than pollution control, as does climate mitigation compared with adaptation, efficient buildings vis-à-vis retrofits, or public transit versus fuelefficient automobiles. These choices suggest that there are 'shades of green' in employment: some are more far-reaching and transformational than others."

\footnotetext{
${ }^{87}$ Manuel Frondel, Nolan Ritter, Christoph M. Schmidt and Colin Vance, "Economic Impacts from the Promotion of Renewable Energy Technologies: The German Experience," Rheinisch-Westfälisches Institut für Wirtschaftsforschung (RWI), Ruhr Economic Papers 156, 2009.

${ }^{88}$ Classic examples of this are whether nuclear or large-scale hydro can be considered green.
} 


\section{"Traditional" Measures}

Slaper and Krause note there are two general ways to measure green jobs: a production-based approach, which reflects green business activities, and a jobs-based measure. ${ }^{89}$ The authors note two difficulties with the production approach: 1) most industries produce green and nongreen goods and services, so making distinctions is difficult; and 2) industries that use green inputs and processes in the production of non-green products and services are not necessarily green. $^{90}$

Slaper and Krause further split these jobs measures into two approaches: an industry approach and an occupational approach. The industry approach counts all jobs at firms that produce green jobs or services, while the occupational approach counts jobs that make production greener, regardless of the output of the firm. Slaper and Krause outline differences in job counts based on the industry approach versus the occupational approach for Oregon, Michigan and Washington, and also find substantial differences in occupational counts for different green-job areas. For instance, some occupational counts may be biased by affiliation with primarily "green services."

The U.S. Bureau of Labor Statistics uses two similar approaches for measuring green jobs:

(1) the output approach, which identifies establishments that produce green goods and services and counts the associated jobs, and (2) the process approach, which identifies establishments that use environmentally friendly production processes and practices and counts the associated jobs. The output approach identifies jobs related to producing a certain set of goods and services, such as solar panels. The process approach identifies "activities and associated jobs that favorably impact the environment although the product or service produced is itself not 'green.",91

The definition used by the U.S. Bureau of Labor Statistics is likely the most comprehensive and data-driven; it is based on the Green Goods and Services Survey and the Occupational Employment Statistics Survey. The definition offered by the U.S. Bureau of Labor Statistics (BLS) is that green jobs are: ${ }^{92}$

A. Jobs in businesses that produce goods or provide services that benefit the environment or conserve natural resources.

B. Jobs in which workers' duties involve making their establishment's production processes more environmentally friendly or use fewer natural resources.

89 Timothy F. Slaper and Ryan A. Krause, "The Green Economy: What Does Green Mean?" Indiana Business Review 84,3 (2009) 10-13.

90 Of course, that argument can also be used to say that an industry that uses non-green products and services in the production of green goods and services is not necessarily green, either.

91 United States Bureau of Labor Statistics, "Overall approach to measuring green jobs."

92 United States Federal Register, Notices, v. 75, n. 182. 
Green jobs in the U.S. are generally measured using the output approach. The Bureau of Labor Statistics also provides a detailed breakdown of industries where green goods and services are classified, by six-digit NAICS code. In the final definition, there are 333 industries that fall into five categories. The categories are: energy from renewable resources (58); energy efficiency (140); pollution reduction and removal, greenhouse gas reduction, and recycling and reuse (124); natural resource conservation (75); and environmental compliance, education and training, and public awareness (45)..$^{93}$

\section{An Alternative Definition}

The definitions offered in the literature and in practice are informally and formally inconsistent, and consequently provide little guidance for policy-makers. The green classification appears to be at least partially arbitrary. For instance, using the "industry approach" advanced by Slaper and Krause, a plant that manufactures solar panels but uses coal-based electricity is considered green. ${ }^{94}$ Moreover, an accountant who works at the same plant is a green employee, but an accountant performing the same services to some other manufacturing company is not green. In considering the occupational approach, an accountant who performs all work electronically (and hence does not waste paper) is a green employee.

Bezdek et al. measure the size of the environmental-protection sector in the U.S. and find that the vast majority of jobs in the environmental-protection industry are standard, and that even within environmental companies the majority of employees are not classified as environmental specialists. ${ }^{95}$ A case in point is that the occupational job description of "a typical wind turbine manufacturing company" that is essentially the same as that of a company manufacturing other (non-green) products.

Most industries, firms and employees have access to or utilize some range of green and nongreen inputs and production processes. As a consequence, output from a given firm can simultaneously be green and non-green depending on the perspective of the observer. As an alternative to the current interest in promoting green industries and practice, we suggest that the most important metric and test is the energy used in the production of a good, and the amount of greenhouse gases emitted as a by-product. That is, energy intensity and greenhouse gas emission intensity are the most important to measure and track. Reducing energy use and GHG emissions, while keeping output constant, can be good for the environment and improve productivity as well. This is an appropriate measure of greenness in a firm, industry and economy. The added benefit is that it provides a simple, non-arbitrary yardstick with which to measure performance.

We avoid the issue of "what is a green job" by considering dirty inputs (energy) and dirty outputs (greenhouse gas emissions) to evaluate the relative "greenness" of Canadian industries. Statistics Canada publishes annual data on energy use (direct), greenhouse gas emissions (direct), energy intensity (direct and indirect), and greenhouse gas emission intensity (direct and indirect) by industry according to the System of National Accounts. Ranking industries by energy intensity and GHG emission intensity, we can construct the relative "greenness" of each industry, in terms of its environmental damage per dollar of output.

\footnotetext{
93 See http://www.bls.gov/green/ for the full list of industries.

94 Slaper and Krause, "The Green Economy: What Does Green Mean?"

95 Bezdek, Wendling and DiPerna, "Environmental Protection, the Economy and Jobs."
} 


\section{RELATIVE “GREENNESS" OF CANADIAN INDUSTRIES}

Energy use and greenhouse gas emissions are two different ways of evaluating the relative greenness of Canadian industries. While not all emissions are due to energy use, the U.S. Energy Information Administration estimates 86 per cent of U.S. GHGs are related to energy consumption. ${ }^{96}$ As energy is an input into production, looking at energy use and energy intensity (energy use per dollar of output) provides a gauge of relative greenness from the input side. Energy intensity also tells us the energy cost per unit of output.

While examining the energy use of different Canadian industries is informative for evaluating relative dirtiness, what policy-makers are truly concerned about are greenhouse gas emissions. This has driven the current infatuation with green jobs: the desire to reduce pollution while still maintaining employment. Examining greenhouse gas emissions and emissions intensity allows us to evaluate the pollution cost per unit of output across industries.

We start by examining energy use; Statistics Canada infers GHG emissions from energy-use data, calculating emissions per quantity of various forms of energy and combining with data on energy use by industry. Thus, analyzing energy use is a good starting point before moving on to emissions.

\section{Energy Use and Energy Intensity}

Table 7 displays energy use by the 18 System of National Accounts (SNA) sectors of the Canadian economy. There are four large energy-using sectors accounting for 73 per cent of energy use in 2008: Manufacturing, Utilities, Mining and Oil and Gas Extraction, and Warehousing and Transportation. In 2008, these four sectors accounted for only 33 per cent of Canada's total output (in 2008 dollars). The "cleanest" sector is Educational Services, accounting for 0.001 per cent of total energy use (and just two per cent of the Canadian economy).

96 U.S. Energy Information Administration, Energy in Brief, "What are greenhouse gases and how much are emitted by the United States?", http://www.eia.gov/energy_in_brief/article/greenhouse_gas.cfm. 
TABLE 7: ENERGY USE BY SECTOR (2008)

\begin{tabular}{|c|c|c|c|}
\hline Sector & $\begin{array}{l}\text { Energy Use } \\
\text { (terajoules) }\end{array}$ & $\begin{array}{l}\text { Share of Total } \\
\text { Energy Use }^{97}\end{array}$ & $\begin{array}{c}\text { Change in Energy } \\
\text { Use Since } 1990 \\
(\%)\end{array}$ \\
\hline Agriculture, Forestry, Fishing and Hunting & 232,173 & 0.03 & 4.61 \\
\hline Mining and Oil and Gas Extraction & $1,316,017$ & 0.16 & 38.35 \\
\hline Utilities & $1,678,624$ & 0.21 & 27.17 \\
\hline Construction & 170,896 & 0.02 & 37.92 \\
\hline Manufacturing & $1,938,116$ & 0.24 & -3.01 \\
\hline Wholesale Trade & 211,931 & 0.03 & 43.27 \\
\hline Retail Trade & 198,008 & 0.02 & 7.14 \\
\hline Warehousing and Transportation & $1,052,797$ & 0.13 & 27.58 \\
\hline Information and Cultural Industries & 28,968 & 0.00 & -1.55 \\
\hline FIRE (Finance, Insurance, Real Estate) & 438,375 & 0.05 & 31.45 \\
\hline Professional, Scientific and Technical Services & 41,419 & 0.01 & 53.55 \\
\hline $\begin{array}{l}\text { Administrative and Support, } \\
\text { Waste Management and Remediation Services }\end{array}$ & 51,630 & 0.01 & 23.73 \\
\hline Educational Services & 7,214 & 0.00 & 50.42 \\
\hline Health Care and Social Assistance & 60,627 & 0.01 & 52.67 \\
\hline Arts, Entertainment and Recreation & 15,235 & 0.00 & 22.60 \\
\hline Accommodation and Food Services & 62,782 & 0.01 & -4.90 \\
\hline Other Services & 56,789 & 0.01 & 35.68 \\
\hline \multicolumn{4}{|l|}{$\begin{array}{l}\text { Operating, Office, Cafeteria and } \\
\text { Laboratory Supplies }\end{array}$} \\
\hline Government Services & 453,154 & 0.06 & 16.35 \\
\hline Non-Profit Institutions & 84,877 & 0.01 & 48.93 \\
\hline
\end{tabular}

Source: Authors' calculations from Statistics Canada CANSIM Tables 153-0031.

Table 7 also shows that, not surprisingly, energy use has increased in the 18 years for which data is available, in some cases substantially. What is surprising is that three sectors manufacturing, information and cultural industries, and accommodation and food services all had decreases in energy use. Of course, this is only truly noteworthy if output increased or decreased less than energy use.

In addition to total energy use, it is useful to understand how effectively each sector is using its energy inputs - the sector's energy intensity, or energy use per dollar of output. There are two ways to measure energy intensity. The first, direct energy intensity, is simply energy used by a sector (or industry) in production divided by the value of output in that sector. Direct-plusindirect energy intensity takes into account the energy used to produce intermediate inputs that are then used to produce the final output of that sector. Energy intensity using both methods is reported in Table 8.

97 Total Canadian energy use includes the business sector, non-business sector (government and non-profits) and household energy use. In calculating energy-use shares, we exclude household energy use. 
We see in Table 8 that the four highest-energy-using sectors are also among the most energy intensive. When considering only direct energy intensity, there are clear "dirty" sectors utilities, warehousing and transportation, and mining and oil and gas extraction - with intensities far above the other sectors, especially in the case of utilities. However, accounting for indirect energy use substantially changes the ranking. Utilities still have the highest intensity, but manufacturing and the agricultural sector have intensities similar to the oil and gas sector.

\section{TABLE 8: ENERGY INTENSITY BY SECTOR (2008)}

\begin{tabular}{|c|c|c|c|c|}
\hline Sector & $\begin{array}{l}\text { Direct Energy } \\
\text { Intensity } \\
\text { (GJ/ } \\
\text { thousand \$) }\end{array}$ & $\begin{array}{c}\text { Change in } \\
\text { Direct } \\
\text { Intensity Since } \\
1990(\%)\end{array}$ & $\begin{array}{l}\text { Direct plus } \\
\text { Indirect Energy } \\
\text { Intensity } \\
\text { (GJ/ } \\
\text { thousand \$) }\end{array}$ & $\begin{array}{c}\text { Change in D+I } \\
\text { Intensity Since } \\
1990(\%)\end{array}$ \\
\hline Agriculture, Forestry, Fishing and Hunting & 3.38 & -32.02 & 9.37 & -30.96 \\
\hline Mining and Oil and Gas Extraction & 6.29 & -4.72 & 8.31 & -2.12 \\
\hline Utilities & 34.74 & -9.41 & 36.70 & -9.67 \\
\hline Construction & 0.66 & 3.60 & 4.94 & -11.72 \\
\hline Manufacturing & 3.09 & -51.71 & 10.18 & -43.86 \\
\hline Wholesale Trade & 1.57 & -31.87 & 4.08 & -32.53 \\
\hline Retail Trade & 1.51 & -85.17 & 3.72 & -76.60 \\
\hline Warehousing and Transportation & 8.14 & -28.51 & 12.98 & -19.70 \\
\hline Information and Cultural Industries & 0.33 & -155.34 & 2.62 & -55.71 \\
\hline FIRE (Finance, Insurance, Real Estate) & 1.08 & -28.15 & 2.61 & -29.41 \\
\hline Professional, Scientific and Technical Services & 0.35 & -42.06 & 2.24 & -12.82 \\
\hline $\begin{array}{l}\text { Administrative and Support, Waste } \\
\text { Management and Remediation Services }\end{array}$ & 0.93 & -59.11 & 2.73 & -34.42 \\
\hline Educational Services & 1.70 & & 3.34 & \\
\hline Health Care and Social Assistance & 1.17 & 24.16 & 3.13 & 17.00 \\
\hline Arts, Entertainment and Recreation & 0.72 & -68.12 & 3.59 & -24.34 \\
\hline Accommodation and Food Services & 0.96 & -47.27 & 4.15 & -25.30 \\
\hline Other Services & 1.47 & -40.76 & 3.87 & -4.03 \\
\hline $\begin{array}{l}\text { Operating, Office, Cafeteria and } \\
\text { Laboratory Supplies }\end{array}$ & & & 9.02 & \\
\hline Government Services & 1.22 & & 3.46 & \\
\hline Non-Profit Institutions & 2.58 & & 5.04 & \\
\hline
\end{tabular}

Source: Authors' calculations from Statistics Canada CANSIM Tables 153-0031, 153-0032 and 281-0009. Energy intensity is deflated using sector-specific output price indices.

Another consideration in evaluating the greenness of industries is the improvement in energy intensity over time. Energy use has, in general, increased since 1990 and, while energy intensity has improved, for many industries the improvement in energy intensity was not sufficient to offset the increase in energy use. Of particular note is the mining and oil and gas sector, which had a 38-per-cent increase in energy use since 1990 and only a two-per-cent decrease in energy intensity.

While Table 8 displays sector aggregations, the high energy intensity of the agriculture sector does call into question the "greenness" of organic farming, an industry promoted by many green jobs proponents. On the other hand, the agricultural sector ranked sixth in terms of improving direct-plus-indirect energy intensity. 


\section{Greenhouse Gas Emissions and GHG Emission Intensity}

GHG emissions can be used as a metric to further refine and evaluate the "greenness" of Canadian industries. As Statistics Canada calculates greenhouse gas emissions based on energy use, we expect the results to be similar. ${ }^{98}$ Table 9 displays greenhouse gas emissions by SNA sector. As with energy use, the sectors with the largest footprint are utilities, mining and oil and gas extraction, and manufacturing. What distinguishes Table 9 from Table 7 is the fact that the agriculture, forestry, fishing and hunting sector was the fifth-largest producer of emissions in 2008 , producing substantially more than the next largest, wholesale trade.

TABLE 9: GREENHOUSE GAS EMISSIONS BY SECTOR (2008)

\begin{tabular}{|l|c|c|c|}
\hline Sector & $\begin{array}{c}\text { GHG Emissions } \\
\text { (kilotonnes) }\end{array}$ & $\begin{array}{c}\text { Share of Total } \\
\text { GHG Emissions }\end{array}$ & $\begin{array}{c}\text { Change in GHG } \\
\text { Emissions Since } \\
\text { 1990 (\%) }\end{array}$ \\
\hline Agriculture, Forestry, Fishing and Hunting & 72,703 & 0.123 & 16.42 \\
Mining and Oil and Gas Extraction & 120,656 & 0.204 & 35.11 \\
Utilities & 118,582 & 0.201 & 20.82 \\
Construction & 12,403 & 0.021 & 39.45 \\
Manufacturing & 110,553 & 0.187 & -10.82 \\
Wholesale Trade & 11,763 & 0.020 & 40.02 \\
Retail Trade & 7,953 & 0.013 & 6.85 \\
Warehousing and Transportation & 76,074 & 0.129 & 27.17 \\
Information and Cultural Industries & 1,130 & 0.002 & -19.73 \\
FIRE (Finance, Insurance, Real Estate) & 19,029 & 0.032 & 30.67 \\
Professional, Scientific and Technical Services & 1,920 & 0.003 & 55.21 \\
Administrative and Support, Waste & 3,162 & & 25.84 \\
Management and Remediation Services & 311 & 0.005 & 54.34 \\
Educational Services & 2,352 & 0.001 & 54.29 \\
Health Care and Social Assistance & 338 & 0.004 & 30.77 \\
Arts, Entertainment and Recreation & 1,914 & 0.001 & -22.10 \\
Accommodation and Food Services & 2,387 & 0.003 & 28.15 \\
Other Services & & 0.004 & 57.63 \\
Operating, Office, Cafeteria and & 2,896 & & \\
Laboratory Supplies & & 0.031 & \\
Government Services & 331 & 0.005 & \\
Non-Profit Institutions & & & \\
\hline
\end{tabular}

Table 9 also reports the changes in greenhouse gas emissions over time, which are positive, except for the three industries where energy use decreased. By this measure, the majority of Canadian industries are becoming dirtier. Emissions intensity tells us the pollution cost per dollar of output, and evaluating the change in emissions intensity over time gives us a sense of the relative greening of Canadian industries.

98 Statistics Canada infers GHG emissions from energy-use data in the Materials and Energy Flow Accounts. Specifically, emissions per quantity of various forms of energy is calculated and combined with data on energy use by industry. The data on energy use used to calculate emissions includes 10 energy commodities: coal, natural gas, liquid petroleum gases, electricity, coke, motor gasoline, diesel fuel, aviation fuel, light fuel oil and heavy fuel oil.

99 Total Canadian greenhouse gas emissions include emissions from the business sector, non-business sector (government and non-profits) and household emissions. In calculating GHG emission shares, we exclude households. 
In terms of greenhouse gas emission intensity (reported in Table 10), the utilities sector is by far the dirtiest, with direct and indirect intensity 44-per-cent higher than the agricultural sector, the sector with the next-highest intensity. Comparing emission intensity creates a clear ranking of dirty versus clean. Figure 3 displays the intensity comparison graphically.

\section{FIGURE 3: GREENHOUSE GAS EMISSION INTENSITY BY SECTOR (2008)}

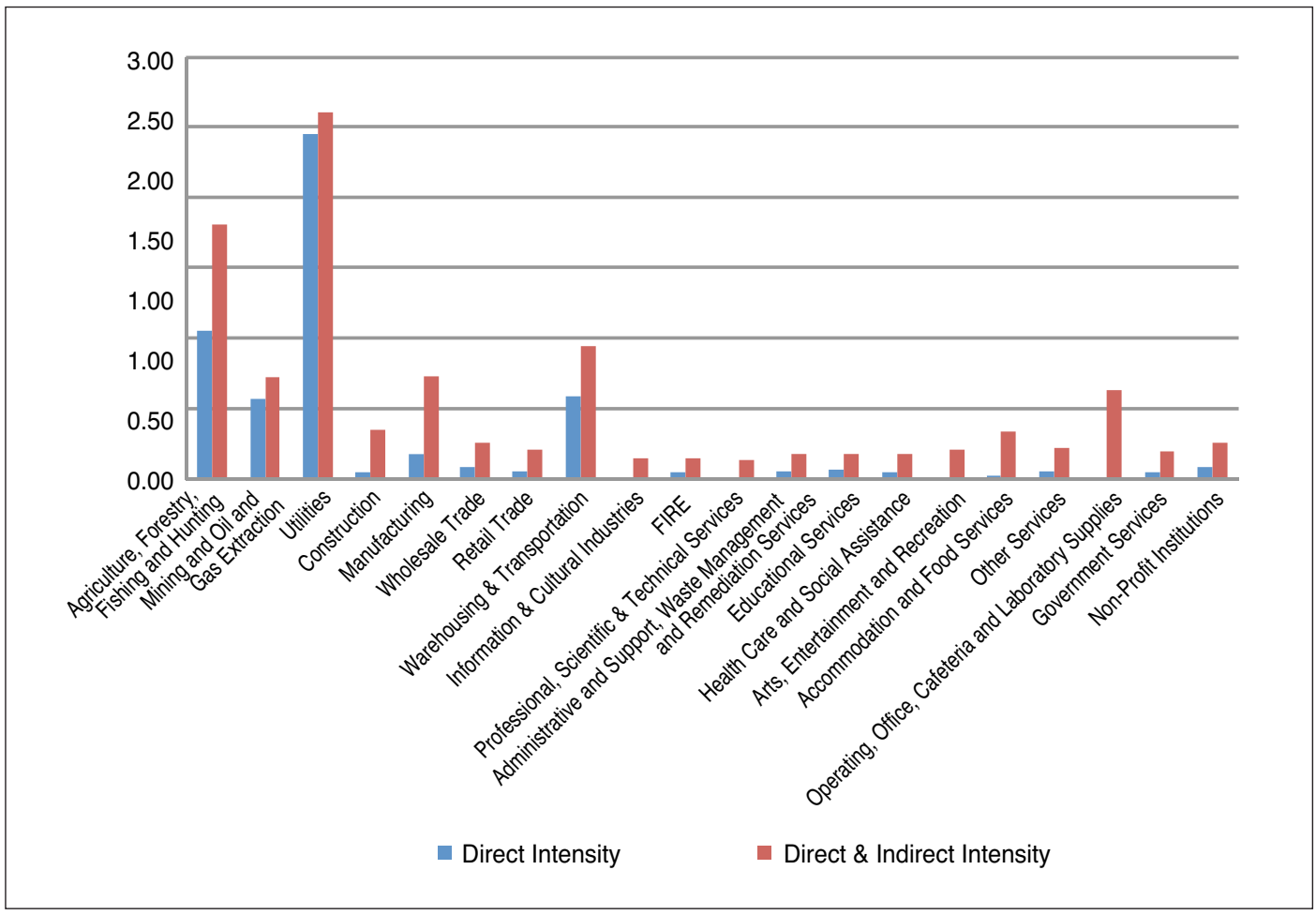

Source: Authors' calculations from Statistics Canada CANSIM Tables 153-0033, 153-0034 and 281-0009. GHG intensity is deflated using sector-specific output price indices.

Figure 3 reflects the importance of considering direct-plus-indirect intensity - that is, including emissions associated with intermediate inputs used in producing final outputs. ECO Canada, in its survey of Canadian environmental employment, identifies industries with the highest concentrations of environmental employment. ${ }^{100}$ The agricultural sector is 11 -per-cent environmental employment, and construction is eight-per-cent environmental employment. Though it has the highest concentration of environmental employment, the agricultural sector is one of Canada's dirtiest in terms of greenhouse gas emission intensity (ranked second) and energy intensity (ranked fourth).

\footnotetext{
${ }^{100}$ Environmental Careers Organization (ECO) Canada, "Profile of Canadian Environmental Employment."
} 
TABLE 10: GREENHOUSE GAS EMISSION INTENSITY BY SECTOR

\begin{tabular}{|c|c|c|c|c|}
\hline Sector & $\begin{array}{l}\text { Direct GHG } \\
\text { Intensity } \\
\text { (tonnes/ } \\
\text { thousand \$) }\end{array}$ & $\begin{array}{c}\text { Change in } \\
\text { Direct } \\
\text { Intensity Since } \\
1990(\%)\end{array}$ & $\begin{array}{l}\text { Direct plus } \\
\text { Indirect GHG } \\
\text { Intensity } \\
\text { (tonnes/ } \\
\text { thousand \$) }\end{array}$ & $\begin{array}{c}\text { Change in D+I } \\
\text { Intensity Since } \\
1990(\%)\end{array}$ \\
\hline Agriculture, Forestry, Fishing and Hunting & 1.06 & -15.69 & 1.81 & -21.36 \\
\hline Mining and Oil and Gas Extraction & 0.58 & -10.21 & 0.72 & -6.86 \\
\hline Utilities & 2.45 & -18.95 & 2.61 & -19.62 \\
\hline Construction & 0.05 & 5.98 & 0.36 & -18.04 \\
\hline Manufacturing & 0.18 & -63.23 & 0.73 & -53.32 \\
\hline Wholesale Trade & 0.09 & -39.43 & 0.26 & -38.43 \\
\hline Retail Trade & 0.06 & -85.74 & 0.21 & -81.41 \\
\hline Warehousing and Transportation & 0.59 & -29.24 & 0.94 & -21.68 \\
\hline Information and Cultural Industries & 0.01 & -201.06 & 0.15 & -62.29 \\
\hline FIRE (Finance, Insurance, Real Estate) & 0.05 & -29.61 & 0.15 & -33.86 \\
\hline Professional, Scientific and Technical Services & 0.02 & -54.72 & 0.14 & -12.18 \\
\hline $\begin{array}{l}\text { Administrative and Support, Waste } \\
\text { Management and Remediation Services }\end{array}$ & 0.06 & -36.97 & 0.18 & -36.45 \\
\hline Educational Services & 0.07 & & 0.18 & \\
\hline Health Care and Social Assistance & 0.05 & 26.76 & 0.18 & 11.63 \\
\hline Arts, Entertainment and Recreation & 0.02 & -50.38 & 0.21 & -24.53 \\
\hline Accommodation and Food Services & 0.03 & -71.42 & 0.34 & -30.21 \\
\hline Other Services & 0.06 & -57.22 & 0.22 & -14.53 \\
\hline $\begin{array}{l}\text { Operating, Office, Cafeteria and } \\
\text { Laboratory Supplies }\end{array}$ & & & 0.63 & \\
\hline Government Services & 0.05 & & 0.20 & \\
\hline Non-Profit Institutions & 0.09 & & 0.26 & \\
\hline
\end{tabular}

Source: Authors' calculations from Statistics Canada CANSIM Tables 153-0033, 153-0034 and 281-0009. GHG intensity is deflated using sector-specific output price indices.

Turning to changes in emission intensity, we see that the majority of sectors experienced large improvements in emission intensity since 1990. The five dirtiest sectors, however, had improvements lower than the 16-sector average of 29 per cent. If this trend continues, the gap between "dirty" and "non-dirty" sectors in Canada will continue to grow.

However, in absolute terms, a reduction of 19.6 per cent, from an emissions intensity of 3.12 in 1990 to an emissions intensity of 2.61 for the utilities sector, is far more significant than the reduction of 62.3 per cent in the information and cultural industries. What matters for the significance of improvements is not just the percentage decrease in emissions intensity, but also the starting point. Based on this amount of relative greening, it is highly likely that the utilities sector created far more green jobs than many of the other Canadian sectors. 


\section{SIGNIFICANCE AND CONCLUSIONS}

This paper has focused on the issue of so-called "green jobs" and their value in contrast to other jobs in the economy. Although gaining in popular use, both as a marketing and policy category, the concept of "green jobs" seems to be primarily definitional rather than functional in practice. It is not codified into tax or occupational codes in North America, a normal approbation of validity. What we find is that the range of definition is large, and often depends on the nature and objectives of the entity seeking to frame or bound the characterization of such jobs within any given economic sector. Additionally, green jobs or occupations typically fall across different traditional industry definitions, making them difficult to quantify consistently.

Does the definition matter in the end? For the purposes of calculating green jobs per subsidy or the efficacy of different programs, perhaps. However, the danger here is confounding goals: The best possible environmental policy may be at odds with "green job" creation. As technology choices have illustrated in the past, government intervention in risks and rewards has a tendency to miss changes over time, and to introduce and reinforce a lack of flexibility into industry. Linking job creation to environmental policy may distort the ultimate policy goals of environmental impact mitigation.

Given the limitations in measurement, we recommend that policy-makers move the focus away from measuring "green employment" and instead focus on associated greenhouse gas emissions and emission intensity, a concept that will allow a more-uniform comparison and measurement. This allows interested parties to evaluate the greening of industries over time, as well as relative to each other. Reducing greenhouse gas emissions is a far better environmental policy than counting and using green jobs as a measure of environmental performance.

This is not to suggest there is no value in using the "green" designation. In the Demand Side Management efforts of many jurisdictions, changes in consumer behaviour can be closely traced to a desire to conform to social norms and standards. Further, given the problems of climate change, economies can benefit from "greening", but need a baseline for monitoring and tracking changes over time. Greenhouse gas emission intensity provides this metric. Indeed, we found the majority of Canadian industries improved their emissions intensity between 1990 and 2008, with the "dirtiest" industries showing the largest absolute improvement. 


\section{About the Authors}

Michal C. Moore, (PhD) is an economist and Professor of Energy Economics at The School of Public Policy at the University of Calgary.

$\mathrm{He}$ is the former chief economist at the U.S. National Renewable Laboratory in Golden Colorado, where he led a research team engaged in examining over-the-horizon issues for the U.S. Department of Energy and developing new methods for cross-cutting analysis. He is an economist and a former commissioner with the California Energy Commission, where he held the designated economist position.

Jennifer Winter, $(\mathrm{PhD})$ is a Research Associate in the Energy and Environmental Policy at The School of Public Policy. Her research is focused on the effects of government regulation on the development of natural resources. Jennifer has authored several research papers for The School, including two on Canadian energy literacy. Prior to joining The School, she worked at Human Resources and Skills Development Canada in Ottawa, analysing Canadian labour markets. 


\title{
ABOUT THE SCHOOL OF PUBLIC POLICY
}

The School of Public Policy will become the flagship school of its kind in Canada by providing a practical, global and focused perspective on public policy analysis and practice in areas of energy and environmental policy, international policy and economic and social policy that is unique in Canada.

The mission of The School of Public Policy is to strengthen Canada's public service, institutions and economic performance for the betterment of our families, communities and country. We do this by:

- Building capacity in Government through the formal training of public servants in degree and nondegree programs, giving the people charged with making public policy work for Canada the hands-on expertise to represent our vital interests both here and abroad;

- Improving Public Policy Discourse outside Government through executive and strategic assessment programs, building a stronger understanding of what makes public policy work for those outside of the public sector and helps everyday Canadians make informed decisions on the politics that will shape their futures;

- Providing a Global Perspective on Public Policy Research through international collaborations, education, and community outreach programs, bringing global best practices to bear on Canadian public policy, resulting in decisions that benefit all people for the long term, not a few people for the short term.

\author{
The School of Public Policy \\ University of Calgary, Downtown Campus \\ 906 8th Avenue S.W., 5th Floor \\ Calgary, Alberta T2P $1 \mathrm{H} 9$ \\ Phone: 4032107100
}

\section{DISTRIBUTION}

Our publications are available online at www.policyschool.ca.

\section{DISCLAIMER}

The opinions expressed in these publications are the authors' alone and therefore do not necessarily reflect the opinions of the supporters, staff, or boards of The School of Public Policy.

\section{COPYRIGHT}

Copyright (c) 2013 by The School of Public Policy.

All rights reserved. No part of this publication may be reproduced in any manner whatsoever without written permission except in the case of brief passages quoted in critical articles and reviews.

\section{ISSN}

1919-112x SPP Research Papers (Print) 1919-1138 SPP Research Papers (Online)

\section{DATE OF ISSUE}

October 2013

\section{MEDIA INQUIRIES AND INFORMATION}

For media inquiries, please contact Morten Paulsen at 403-453-0062.

Our web site, www.policyschool.ca, contains more information about The School's events, publications, and staff.

\section{DEVELOPMENT}

For information about contributing to The School of Public Policy, please contact Courtney Murphy by telephone at 403-210-7201 or by e-mail at cdmurphy@ucalgary.ca. 


\section{RECENT PUBLICATIONS BY THE SCHOOL OF PUBLIC POLICY}

\section{ENHANCING THE ALBERTA TAX ADVANTAGE WITH A HARMONIZED SALES TAX}

http:/ / policyschool.ucalgary.ca/ ?q=content/ enhancing-alberta-tax-advantage-harmonized-sales-tax

Philip Bazel and Jack M. Mintz | September 2013

\section{ACCOUNTABILITY BY DESIGN: MOVING PRIMARY CARE REFORM AHEAD IN ALBERTA}

http:/ / policyschool.ucalgary.ca/ ?q=content/accountability-design-moving-primary-care-reform-ahead-alberta Dr. Shannon M. Spenceley, Cheryl Andres, Janet Lapins, Dr. Robert Wedel, Dr. Tobias Gelber, L.M. Halma | September 2013

\section{WIRELESS COMPETITION IN CANADA: AN ASSESSMENT}

http:/ / policyschool.ucalgary.ca/?q=content/ wireless-competition-canada-assessment Jeffrey Church and Andrew Wilkins | September 2013

THE CANADIAN MANUFACTURING SECTOR, 2002-2008: WHY IS IT CALLED DUTCH DISEASE?

http:/ / policyschool.ucalgary.ca/?q=content/ canadian-manufacturing-sector-2002-2008-why-it-called-dutchdisease

Stephen Gordon | September 2013

REDISTRIBUTION OF INCOME: POLICY DIRECTIONS

http:/ / policyschool.ucalgary.ca/?q=content/redistribution-income-policy-directions James Davies | August 2013

INCOME INEQUALITY AND INCOME TAXATION IN CANADA: TRENDS IN THE CENSUS 1980-2005 http:/ / policyschool.ucalgary.ca/ ?q=content/income-inequality-and-income-taxation-canada-trends-census1980-2005

Kevin Milligan | August 2013

INCOME INEQUALITY, REDISTRIBUTION AND ECONOMIC GROWTH http:/ / policyschool.ucalgary.ca/?q=content/income-inequality-redistribution-and-economic-growth Bev Dahlby and Ergete Ferede | August 2013

DIPLOMACY, GLOBALIZATION AND HETEROPOLARITY: THE CHALLENGE OF ADAPTATION http:/ / policyschool.ucalgary.ca/?q=content/ diplomacy-globalization-and-heteropolarity-challenge-adaptation Daryl Copeland | August 2013

UNHEALTHY PRESSURE: HOW PHYSICIAN PAY DEMANDS PUT THE SQUEEZE ON PROVINCIAL HEALTH-CARE BUDGETS

http:/ / policyschool.ucalgary.ca/?q=content/ unhealthy-pressure-how-physician-pay-demands-put-squeezeprovincial-health-care-budgets

Hugh M. Grant and Jeremiah Hurley | July 2013

TRENDS, PEAKS, AND TROUGHS: NATIONAL AND REGIONAL EMPLOYMENT CYCLES IN CANADA http:/ / policyschool.ucalgary.ca/?q=content/trends-peaks-and-troughs-national-and-regional-employmentcycles-canada

Ronald Kneebone and Margarita Gres | July 2013 